\title{
Education Empowerment Model for the Disabled Learners: A Case Study at Cicendo School for Special Education
}

\author{
Mustofa Kamil ${ }^{1}$, Yanti Shantini ${ }^{1} \& \operatorname{Sardin}^{1}$ \\ ${ }^{1}$ Department of Nonformal and Continuing Education, Faculty of Education, Indonesia University of Education, \\ Indonesia \\ Correspondence: Mustofa Kamil, Department of Nonformal and Continuing Education, Faculty of Education, \\ Indonesia University of Education, Jl. Dr. Setiabudhi No. 229 Bandung, Indonesia. E-mail: \\ muskamil14@gmail.com
}

Received: October 7, 2014 Accepted: May 6, 2015 Online Published: June 29, 2015

doi:10.5539/ies.v8n7p139 URL: http://dx.doi.org/10.5539/ies.v8n7p139

\begin{abstract}
This paper originates from a study conducted to examine the challenges faced by the Schools for Special Education (SLB) in their effort to empower people living with disabilities. The study aimed: 1) to describe the stages involved in the education for empowerment of the disabled groups through schools for special education, 2) to present an education model appropriate for the empowerment of special groups, especially people living with disabilities and, 3) to explain the constraints and challenges faced by institutions in the empowerment of people living with disabilities. The study concludes that "an education empowerment model for the people living with disabilities can lead to formation of strong groups which are able to advocate for their own needs. In addition, this model can contribute to the improvement of knowledge and skills of the disabled persons.
\end{abstract}

Keywords: working groups (employees), special education, people living with disabilities, empowerment, education

\section{Introduction}

Disability is always associated with physical, mental and or visual impairements. Most communities believe that being disabled is an indirect restriction to properly accomplish common tasks or activities. Therefore, the term disabled is used to define people with varying disabilities, including the physically crippled, mentally handicapped, and visually impaired. Disability is derived from the word people with different abilities. The World Health Organization (2014) refers to disability as a complex phenomenon, reflecting the interaction between features of a person's body and features of the society in which he or she lives. The social model perceives disability as a complex collection of conditions, many of which are created by the social environment (Langtree, 2010). This makes the promotion of equality and advocacy for the handicapped world-wide a difficulty task to perform because of such a negative attitude by society towards their condition.

In Indonesia, people with disabilities are considered a burden, dependants, and useless people or unproductive citizens, who are unable to exercise their duties and responsibilities (Irwanto et al., 2010). The situation is worsened by the lack of government policies or limited knowledge of the community members about the existing policies which support disability rights.

Studies on disability continue to indicate that people faced with adverse disabilities live an oppressive life facing the dangers of poverty, poor health, low education and many others. In regard to education and job prospect, the disabled not only face the problem of limited access, but also are discriminated even after they have obtained qualifications. This makes it true that issues surrounding disability baiscally revolve around accessing social, cultural and economic rights (Dobhal, 2008). In regard to health, the people living with disabilities are also discriminated, though they are entitled to living a health life. They face difficulties to accessing better health services, which include sexual and reproductive health services. Limited or lack of support or aid and or adequate sanitary material. Besides, it is true that most of the disabled people are poor. According to Hawking, 'majority of people with disabilities in the world have an extremely difficult time with everyday survival, let alone productive employment and personal fulfillment' (World Health Organiztion, 2011).

The current number of disabled people world-wide is estimated to be about a billion people, making up $15 \%$ of 
the world's total population (Chan \& Zoelick, 2011). This figure is higher than $10 \%$ reported in 1970 (World Health Organization, 2011). It has been established that in Indonesia, the prevalence of disability ranges between 10 and 15 percent, which is comparable to the global findings presented in the recent World Report on Disability (Adioentomo, Mont and Irwanto, 2014). However, in a Health and Demographic census conducted by the Central Bureau of Statistics and the Board of Family Planning and National Coordination (BKKBN) conducted from(2002 to 2003), it ismentions that the population of the disabled people is about $5 \%$ or approximately 10 million people (National Family Planning Coordinating Board, 2003).

This implies that the number of disabled people is high and needs proper attention. Based on this brief introduction, this paper therefore, focused on examining the efforts made to empower people living with disabilities (PLWDs) through education programs in Bandung.

\section{Theoretical Review}

Society empowerment is a deliberate effort to facilitate local society to plan, decide and manage local resources through collective actions and networking. According to Esplen, Heerah, and Hunter (2006) right from the mid 1980 s, empowerment has become common in the development field. In regard to disability, the term empowerment generally covers: inclusion, participation, accessibility, ability and or competencies; and strength and individual weaknesses. Empowerment concept refers to individual strength and competencies, natural helping systems, and methods or approaches that can contribute to positive change (Rappaport, 1981, 1984; Perkins \& Zimmerman, 1995).

In otherwords, empowerment focuses on strength and weaknesses of society with the aim to create individual or group social change (Perkins \& Zimmerman, 1995). The aim of education empowerment model is to create self-reliant individuals in society. For empowerment to occur, there several steps which may be considered, among them is awareness creation and character building. Awarenes creation is composed of two important components, which are: the ability to know and the ability to interpret immediate surroundings/circumstances (Trigonometry, 2005). In reference to Freire (1993), awareness creation is in otherwords, conscientization which is intepreted as a change in people's attitude, perceiption and of course behavior. It is based on value assumptions of human equality, freedom to knowledge and culture, and people's right to opinions and the will to act (Dobhal, 2008). Through the study of literature, it has been established that empowerment can be achieved through "group formation of the sensitized disabled people".

Indonesia's National Disability Act (1997) defines disabilityas a condition of being limited physically, mentally and in vision, hence affecting one's dailyactivities. Disabilities are categorized as either physical handicaps, mental disabilities and visual impairements. Empowerment in disability aims to construct or to create power, leading to equal opportunities and improved performance of the people with disabilities. In other words, empowerment as concept aims to change people's attitude about disability. There are several models used to explain this situation, such models were formed as a step forward for inclusion of people with varying abilities in today's environment.

In reference to Michigan Disability Rights Coalition (MDRC) (2014) disability models are instruments required to clarify impairment and help governments and communities devise means for meeting the needs of disabled people. They are an important framework which describe and clarify disability issues, and also substantiate the perceiptions of the founders and developers of such models. There are several models developed in relation to disability, they explain community perceiptions, and attitudes towards disabilities. In this study, we examined the education empowerment model used by Cicendo school of special education to empower the disabled employees.

Understanding policies regarding handicapped can be clarifies in regard to the development of vocational rehabilitation approaches. The school conducts its empowerment through education by integrating two models in the process of empowerment. Article 4(8) line 2 issued in 1997, states that 'vocational rehabilitation is a comprehensive and integrated approach for the empowerment of the disabled, intended to enhance skills and their competencies' (Indonesia's National Disability Act, 1997).

One of the forms for this vocational rehabilitation is training of the handicapped. Vocational rehabilitation trainings are a set of learning processes; concepts referring to strategies of teaching and student evaluation and assessment. Thus, the process is comprised of learning preparation, learning implementation and learning evaluation. Learning process is an education interaction process between the instructor and the student to create a mutual relationship. There are some principles in the teaching and learning process as mentioned by psychologists, which may include; motivation, character building, progress report and the outcome of the teaching-learning processes. Besides, learning process also involves feedback, response, trial and error, and 
transfer that can either affect the student in a positive or negative way. In the learning context, strategy is a method used by instructor to create a supporting condition for the students to learn in order to attain optimal results.

\section{Research Methodology}

This study focuses on the empowerment of handicapped through the formation an education worker empowerment model. The data was taken based on a set of instruments which included questionnaires, interview, observation, and field trials. The data was obtained by conducting several surveys, and with the use of a comprehensive set of approac hes. In order to develop the model, data analysis was conducted using qualitative ways of analysis. Variables and there operations in this research are illustrated as below:

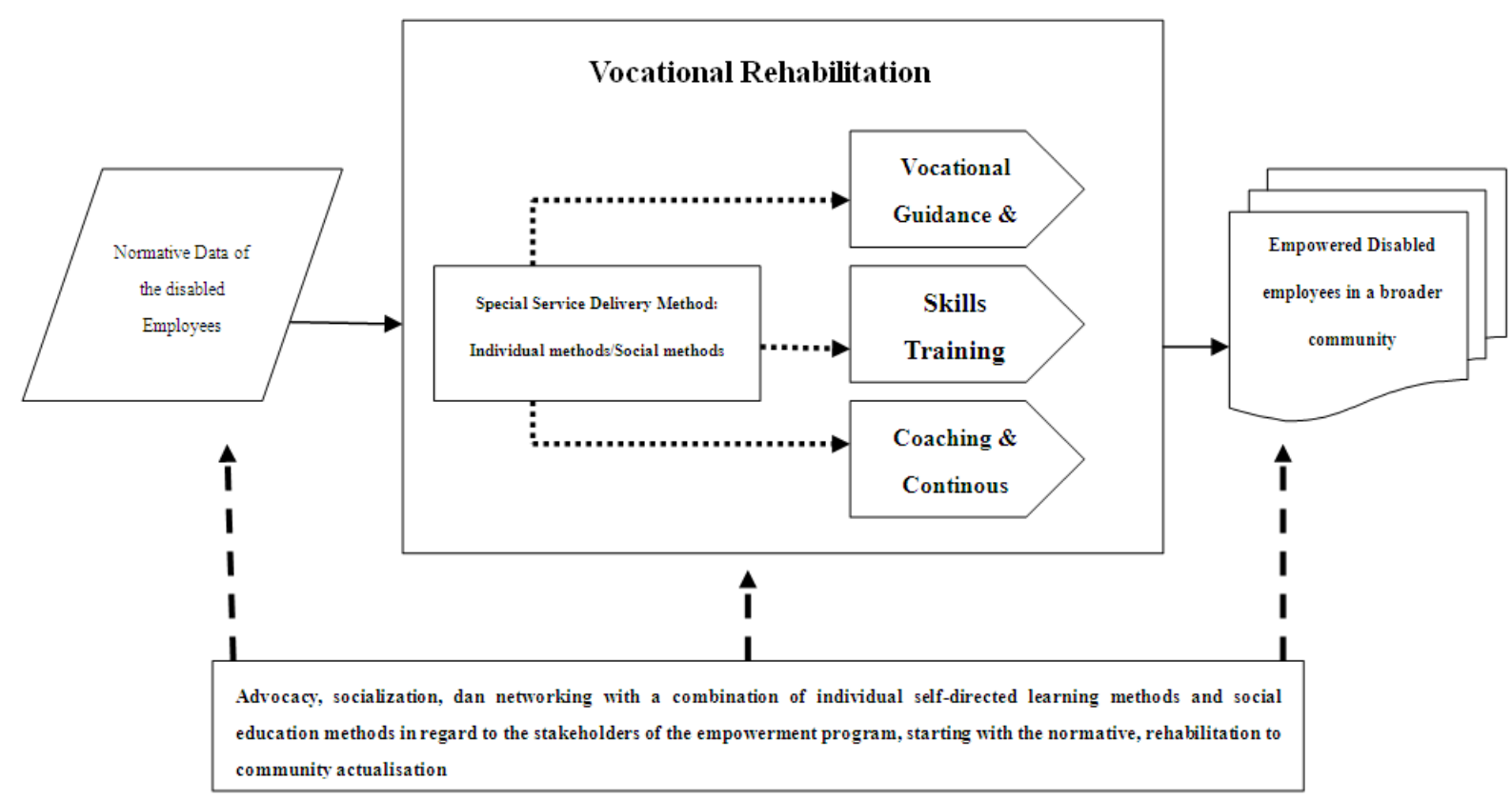

Figure 1. Education empowerment model for the disabled employees

The target populations of the study were students at the School for the Retarded Children in Cicendo Bandung, however, a sample of 57 students were taken as the total participating number. This number consisted of 32 students from junior high school, while 25 persons were students from the senior high school. This implies that the participating samples were students drawn from both the junior and senior high schools for special education in Cicendo.

During the field study, the primary data was obtained from the respondents, or informants using a variety of techniques. These techniques included direct observation of the respondents, deep interviewing, and also discussions were held with community figures surrouding Cicendo. Whereas, on the one hand, secondary data was obtained through the study of documents and neccessarfy literature provided from the school.

\section{Findings}

This part, presents findings from the field. The study aimed: to descibe a clear view about the stages involved in the education empowerment model for the disabled groups at the school for special education, to present an education model appropriate for the empowerment of special groups, especially people living with disabilities, and to explain the constraints and challenges faced by institutions in the empowerment of people living with disabilities.

In regard to the objectives, the findings are presented in a simplified way. As in reference to the data obtained during the field studies, through interviews, and documentation analysis, the steps of program implementation in the effort to format working groups during empowerment of the disabled participants consisted of three stages:

Preparation stage, which consisted of: writing activity proposal in line with the guide provided by Directorate 
General of Higher Education (Dikti) regarding the national strategies for empowerment of the disadvantaged groups; coordination and preparation of the instruments required for program implementation in reference to the prevailing national guide; assessing and analyzing the needs of the participants regarding their situation; arranging and writing down the conceptual model and preparing the instruments for program operation at Cicendo school of special education; and communicating/holding technical discussions with the teachers and stakeholders at the school for retarded children in Cicendo, in order to cooperate and support the study.

Implementation stage-at this stage, empowerment of handicapped involved six main activities: promotion of the program among stakeholders and participants, recruitment and training students, the distribution and creation of working groups and activity facilitation and provision of guidance.

Program facilitation-program facilitation phase aimed to build strong patterns and functional training systems which meet the set standards by the Ministry of Education and Culture of the Republic of Indonesia. This is aimed at building the confidence and self-reliance of the trainees to keep trying and working in their daily life situation.

The design of conceptual model applied in the program of the formation of working group in empowering handicapped worker is aimed at increasing the service quality of the students in Public School for Retarded Children of Cicendo. The model is gained from the understanding and application conceptually regarding:1) the model of materials developed covering the designs and the needs analysis -based preparation in the target school; 2) strategy, method, and learning media in the formation of working group that is hypothetically considered to be able to improve the learning quality and students' competence; 3) the development of evaluation model is the result of the working group formation that can improve the quality of the learning service and further the students' competence in the target school. The obstacles and problems in the formation of working groups in empowering handicapped workers are listed below:

- Communication restriction inhibits the learning to progress successfully. It is resulted in passive learning.

- Tutors and facilitators ability to understand the cue language used by students is lack so that the material is not smoothly delivered. For example in the case of informing sewing matters.

- Students are not really eager and active to put forward their opinion about the learning they have. The lack of references and literatures regarding the topic of sewing skills.

\section{Conclusion}

To design a model program for 'workingdisabled groups' in the effort to empower them demands a better stand point. This means that better training programs which accomodate the demands of the disabled are highly required, because trainings can lead tobetteroutcomes, and of course improved output in regard toquality. The schoolfor Mentally Retarded Children in Cicendo looks at the learningprocess as a core component which very important in the empowering process of the disabled. Based onthis, the neccessity for such a model in regard to life skillsand knowledge enhancement among the disabled is very essential. It should therefore, be given good attention, scince it can help empower the disadvantaged people. It is expectedthatthrough thismodel, the disabled people can perform their duties independently while at work.

\section{References}

Adioetomo S. M., Mont, D., \& Irwanto. (2014). Persons with Disabilities in Indonesia: Empirical Facts and Implications for Social Protection Policies. Lembaga Demografi, Fakultas Ekonomi Universitas Indonesia.

Chan, M., \& Zoelick, B. R. (2011). Preface-World Report on Disability, World Health Organization. WHO Library Cataloguing-in-Publication Data, 2011. Retrieved June 29, 2015, from http://www.who.int/disabilities/world_report/2011/report.pdf

Dobhal, H. (2008). Able and Willing: Disability is not Inability. Combat Law, 7(1).

Esplen, E., Heerah, S., \& Hunter, C. (2006). Women's empowerment: An annotated bibliography. Brighton: Bridge, Institute of Development Studies.

Freire, P. (1993). A Critical Encounter. USA and Canada: Published by Routledge.

Indonesia's National Disability Act. (1997). B. Act of the Republic of Indonesia Number 4, of 1997, Concerning Disabled People. Retrieved June 29, 2015, from http://www.refworld.org/pdfid/4da2d1b92.pdf

Irwanto et al. (2010). The situation of people with disability in Indonesia: A desk review. Centre for Disability Studies, Universitas Indonesia. Jakarta.

Langtree, I. (2014). Definitions of The Models of Disability: Brief Synopsis: Glossary list of definitions and 
explanations of the Models of Disability in society today. Retrieved September 19, 2014, from http://www.disabled-world.com

Michigan Disability Rights Coalition (MDRC). (2014). Models of Disability. Retrieved October 7, 2014, from http://www.copower.org/model of disability

National Family Planning Coordinating Board. (2003). Indonesia Demographic and Health Survey 2002-2003, Statistics Indonesia. Jakarta: Indonesia. Retrieved June 29, 2015, from http://dhsprogram.com/pubs/pdf/FR147/FR147.pdf

Perkins, D. D., \& Zimmerman, A. M. (1995). Empowerment Theory, Research, and Application. American Journal of Community Psychology, 23(5). Retrieved October 7, 2014, from http://my.venderbilt.ed/perkins/files/2011

Trigonometry, J. (2005). Theory of awareness: Physics Forums. Retrieved October 7, 2014, from https://www.physicsforums.com

World Health Organization. (2011). World Report on Disability. Malta: WHO Press. Retrieved September 19, 2014, from http://www.who.int/disabilities/world_report/2011/

World Health Organization. (2014). Disabilities. Retrieved September 18, 2014, from http://www.who.int/topics/disabilities/en/

\section{Copyrights}

Copyright for this article is retained by the author(s), with first publication rights granted to the journal.

This is an open-access article distributed under the terms and conditions of the Creative Commons Attribution license (http://creativecommons.org/licenses/by/3.0/). 